\title{
GOLD MINING IN IGUN-IJESHA, SOUTHWEST NIGERIA: IMPACTS AND IMPLICATIONS FOR WATER QUALITY
}

\author{
${ }^{1}$ Ayantobo, O.O., ${ }^{1}$ J.A. Awomeso, ${ }^{1}$ G.O. Oluwasanya, ${ }^{2}$ B.S. Bada and ${ }^{2}$ A.M. Taiwo \\ ${ }^{1}$ Department of Water Resources Management and Agricultural-Meteorology \\ ${ }^{2}$ Department of Environmental Management and Toxicology, \\ Federal University of Agriculture, PMB 2240, Abeokuta (FUNAAB), Nigeria
}

Received 2014-02-12; Revised 2014-03-07; Accepted 2014-05-08

\begin{abstract}
This study was carried out in Igun-Ijesha, Osun State, Nigeria to determine the likely hotspots of water contamination for future treatment trials. Water quality analyses were based on physico-chemical and heavy metal parameters of surface and ground water collected from the study community. A total of thirty-eight water samples were collected between September 2012 and February 2013 and analyzed using standard procedures. Concentrations of heavy metals were determined using Atomic Absorption Spectrophotometer. Results showed that water samples within the gold mining community are contaminated and the hydrochemistry varied with seasons. The values of magnesium, turbidity, total dissolved solids, electrical conductivity and $\mathrm{pH}$ during the period of sampling ranged 3.1-42.1 mg/L, 0-150 NTU, 30-560 mg/L, 80$1192 \mu \mathrm{S} / \mathrm{cm}$ and 5.95-8.55 respectively. Chloride, nitrate, phosphate, sulphate and sodium data were within the stipulated limits set by the Nigerian Standards for Drinking Water Quality (NSDWQ). Heavy metal contents of the groundwater were generally higher than those from surface water sampled within the mining district. The values of arsenic, cadmium, chromium, copper, lead, manganese, nickel and zinc, ranged from $0.01-1.20, \quad 0.05-0.52, \quad 0.80-34.80, \quad 0.09-4.30, \quad 0.09-8.30, \quad 0.05-3.94, \quad 0.05-19.6$ and $1.80-29.90 \mathrm{mg} / \mathrm{L}$ respectively. Most of the listed metals have values exceeding the international and national recommended limits. The daily intake of water in the study area poses a potential health threat from long-term exposure to heavy-metals. The study suggests that water safety plans should be developed to safeguard water resource and public health within the mining community.
\end{abstract}

Keywords: Gold Mining, Heavy Metal Pollution, Igun-Ijesa, Surface and Groundwater, Water Quality, Water Safety

\section{INTRODUCTION}

Water is one of the essentials that supports all forms of plant and animal life and it is generally obtained from two principal natural sources; groundwater and surface water such as fresh water lakes, rivers, streams (Awomeso et al., 2010). However, one of the most important environmental issues today is water contaminated with heavy metals because of strong toxicity even at low concentrations (Marcovecchio et al., 2007). Water contamination with light and heavy metals are mainly determined by natural (i.e., weathering, erosion of bed rocks and ore deposits) and anthropogenic (e.g., mining, smelting, industries, agriculture and waste water irrigation) processes (Ettler et al., 2011; García-Lorenzo et al., 2011; Muhammad et al., 2011; Sracek et al., 2011). These processes degrade water quality and impair their use for drinking, domestic, agricultural and industrial purposes (Krishna et al., 2009). The common heavy metals that have been identified in polluted water include arsenic, copper, cadmium, lead, chromium, nickel, mercury and zinc. The release of the metals without proper treatment poses significant danger to Corresponding Author: Ayantobo O.O., Department of Water Resources Management and Agricultural-Meteorology, Federal University of Agriculture, PMB 2240, Abeokuta (FUNAAB), Nigeria Tel: - +234 (0) 8066365964 
water and public health. The danger lies in two aspects. Firstly, heavy metals have the ability to persist in natural ecosystems for an extended period. Secondly, the metals have the ability to accumulate in successive levels of the biological chain, thereby causing acute and chronic diseases (Nomanbhay and Palanisamy, 2005; Lone et al., 2008). Recently, pollution of general environment has increasingly gained a global interest. Contamination of surface and groundwater in gold mining communities is a serious environmental problem in many countries, Nigeria inclusive (Aslibekian and Moles, 2003). Heavy metal contamination of soil and water and related health impact on residents is a persistent social issue and several studies have identified human health risks subject to abandoned mines (Chung et al., 2005; Bada et al., 2012).

In view of the various challenges of pollution, conformation with drinking water quality standards is a concern because of the ability of water to spread diseases within a large population. Although the standards vary from country to country, the objective anywhere is to reduce the possibility of spreading water borne diseases to the barest minimum in addition to being pleasant to drink, which implies that water must be wholesome and palatable in all respects (Edema et al., 2001; Awomeso et al., 2010). In Igun Ijesha gold city, the community depend on surface and groundwater contaminated from mining activities and so far, there is no evidence of any water quality assessment. Therefore, the aim of this study is to evaluate the physicochemical parameters and trace metals in drinking water sources in Igun-Ijesha gold mine area. The assessment is expected to determine water quality status of drinking water in the study area to ensure source and water safety.

\section{MATERIALS AND METHODS}

\subsection{The study Area}

Igun-Ijesha gold city lies between latitudes $7^{\circ} 30^{\prime}$ and $7^{\circ} 35^{\prime} \mathrm{N}$ and between longitudes $4^{\circ} 38^{\prime}$ and $4^{\circ} 42^{\prime} \mathrm{E}$ in Atakumosa West Local Government Council southwestern Nigeria (Fig. 1). The study area is a rural community of about 2,400 to 2,600 people that engage in predominantly in subsistence farming and cocoa plantation. Igun Ijesha is a community with many dilapidated buildings. The city is accessible through a poorly erected bridge. Mapping of the community was done with assistance of the community members. The mapping exercise reveals local knowledge of resources, land use and settlement patterns.

The mine locations are within one of the six (6) classes of the Basement Complex rock that is from slightly migmatised to non-migmatised, meta- sedimentary and meta-igneous rock or simply called the Schist belt. The study area is a part of Ilesa-Ife schist belt (Ademeso et al., 2013). The belt is one of the 11 schist belts documented by Ademeso et al. (2013). The area has two contrasting lithologies separated by NNE trending Ifewara fault zone. The west of the fault is occupied by the amphibole schist, amphibolites, talc-tremolite and pellitic rocks (TML, 1996). The eastern part has quartzite, quartz schist and amphibole schist, The gold deposit occur in the eastern area, thus, the three Local government areas lie on the east of Ifewara fault zone. Gold occurs with ores such as: Pyrite, pyrrhotite and minor chalcopyrite, galena, sphalerite, magnetite and ilmenite. Adjacent to the gold bearing veins the host granite-gneiss has been hydrothermally altered to a sericitechlorite epidote assemblage (with also hematite and pyrite) (NMC, 1987).

\subsection{Field Investigation and Water Sampling}

Igun-Ijesha area was selected for this study primarily due to the presence of gold mining activities in the community. Three surface water and three groundwater sampling points were selected and their coordinates located using a Global Positioning System GARMING 45XLS. The sampling points are shown in Fig. 1.

Sampling was done between September 2012 and February 2013. A total of thirty-eight water samples were collected from both surface and ground water samples in the study area. Water samples were collected with 1.5 L plastic bottles, which had been soaked in $70 \%$ nitric acid for $24 \mathrm{~h}$ and rinsed thoroughly with double distilled water. Samples for trace metal analyses were put into $250 \mathrm{~mL}$ plastic bottles and $2 \mathrm{~mL}$ concentrated Nitric acid added to it. Collected samples were preserved and stored in an ice-chest at a temperature of $4{ }^{\circ} \mathrm{C}$ and transported to the laboratory for analyses. Samples were taken in separate containers for physicochemical and trace metal analysis respectively. Samples for trace metal analysis were each preserved with $0.5 \mathrm{~mL}$ of concentrated nitric acid before transporting to the Central laboratory, University of Ibadan for analysis. During sampling, relevant information like the ambient temperature $\left(31^{\circ} \mathrm{C}\right)$, date of Sampling, time of sampling and seasons of the year were recorded.

\subsection{Sample Analysis}

The methods of laboratory analysis used were those specified in International analytical standards such as APHA for water quality. All equipments were duly calibrated with standards and samples were analysed in two replicates. All tests and laboratory analyses were carried out at the ACEME Analytical Laboratory Limited Canada and International Institute for Tropical Agriculture (IITA) Laboratory, Ibadan. 


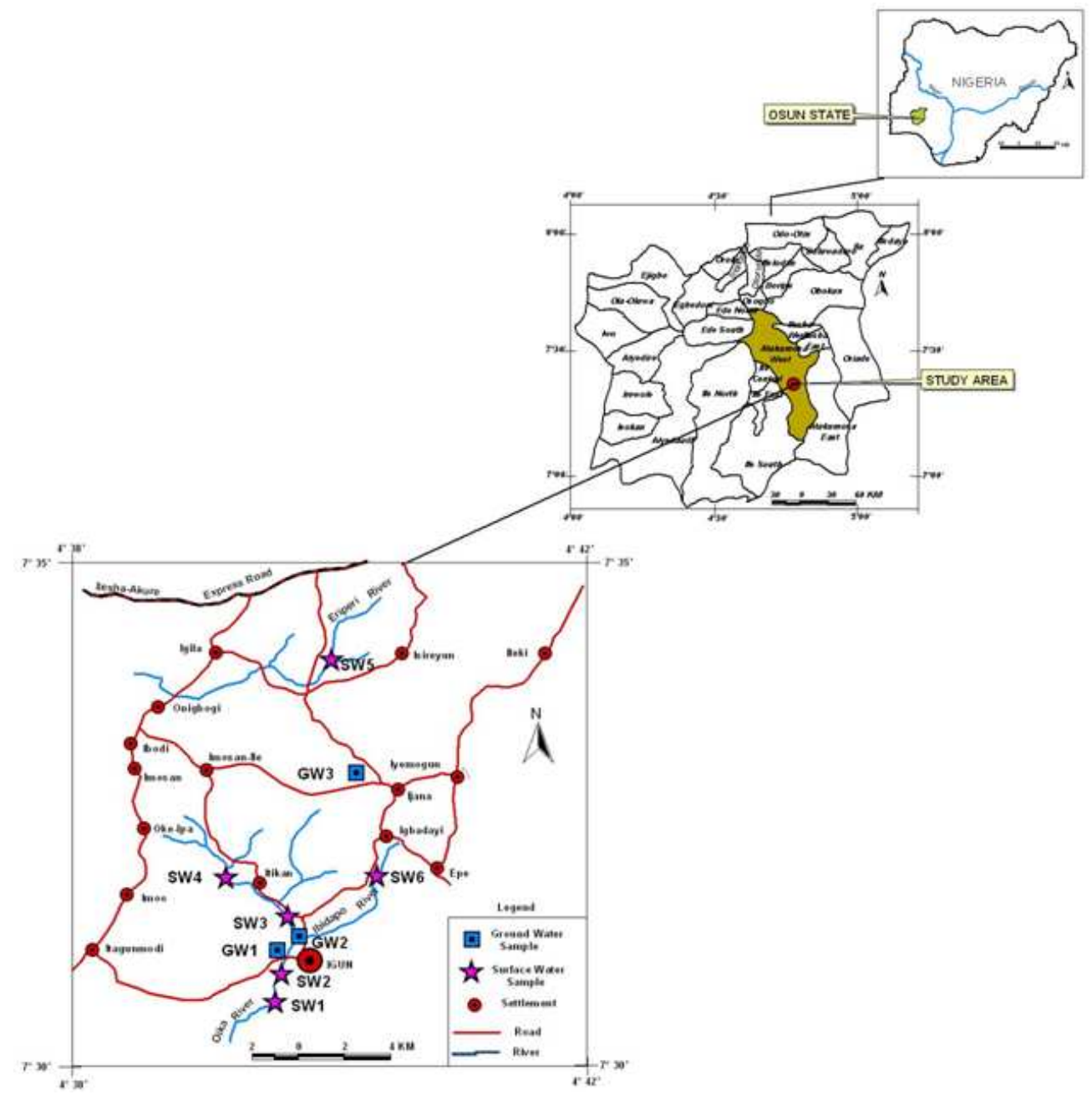

Fig. 1. Map of the study area showing the sampling locations

\subsection{Determination Physico-Chemical Parameters}

Water $\mathrm{pH}$, temperature, Electrical Conductivity (EC), TDS were analyzed in-situ during sampling using $\mathrm{pH} / \mathrm{TDS} /$ Conductivity meter. Turbidity was determined using a Spectrometer (HACH DR/2000). Samples for water soluble anions (sulphate, nitrate, phosphate and chloride) were determined with Ion Chromatography System (ICS) model Dionex ICS 2000. The element used was potassium hydroxide. The ICS analytical column and guard column are AS II HC $(2 \times 250 \mathrm{~mm})$ and AG II HC $(2 \times 250 \mathrm{~mm})$, respectively (Thermo Fischer Scientific Inc, 2012). Samples for cationic water soluble constituents (calcium, magnesium and potassium) were analysed with Dionex DX 500 with CS 12A Analytical column $(4 \times 250$ $\mathrm{mm}$ ) and CG 12A guard column. Details of analytical procedures of both anionic and cationic species can be found in (Taiwo, 2013; Gashi et al., 2013). Standard calibration curves were generated with series of known salt concentrations in the series of 5, 10, 20,50 and $100 \mathrm{ppm}$.

\subsection{Sample Digestion for Heavy Metal Analysis}

Samples for the determination of arsenic, cadmium, chromium, copper, lead, manganese, nickel and zinc were collected with $500 \mathrm{~mL}$ plastic bottles, since such metal may be adsorbed on the wall of glass bottles. About $3 \mathrm{~mL}$ of concentrated Nitric acid was added and the samples were refrigerated at $4^{\circ} \mathrm{C}$ before digestion. The water samples $(100 \mathrm{~mL})$ were digested with $10 \mathrm{~mL}$ concentrated $\mathrm{HNO}_{3}$. The mixture was then heated on a hotplate for 30 min (USEPA, 1989). The extracts were filtered and made to $100 \mathrm{~mL}$ with distilled deionised water. The ready 
digests were sent to ACEME analytical laboratory Canada for heavy metal determination using Inductively Coupled Plasma-Mass Spectrometer (ICPMS).

\subsection{Metal Analysis}

Heavy metals were determined with ICPMS (Agilent 7500ce) at the ACEME Analytical Laboratory in Canada. The ICPMS was equipped with octopole reaction system, which is effective in removing interfering species. Standards were prepared from VWR standard soluble prepared in the series of 5, 10, 20, 50 and $100 \mathrm{ppb}$. The procedures of ICPMS can be read elsewhere in (Taiwo, 2013; Gashi et al., 2013).

\section{RESULTS}

\subsection{Physical and Chemical Parameters}

Table 1 (a and b) show the data collected for individual surface and ground water samples while Table 2 (a and b) summarizes the physico-chemical parameters with respective WHO/NSDWQ standards. The measured $\mathrm{pH}$ gives the general indication that the water samples range from neutral to alkaline for wet season and slightly acidic during dry season. The highest desirable level for $\mathrm{pH}$ stipulated for drinking and domestic purposes is within the range of 6.5 to 8.5 (WHO, 2004). Electrical conductivity values in all the water samples varied from $103 \mu \mathrm{S} / \mathrm{cm}$ (SW5) to 1192 $\mu \mathrm{S} / \mathrm{cm}(\mathrm{GW} 3)$ for dry season and $80-620 \mu \mathrm{S} / \mathrm{cm}$ in GW2 and GW1 samples respectively, for wet season. With the exception of GW3 sample with the value of $1192 \mu \mathrm{S} / \mathrm{cm}$, all other water samples are within the permissible limit of $1000 \mu \mathrm{S} / \mathrm{cm}$ for EC in drinking water (WHO, 2004).
The turbidity values in the water samples varied between 5 FTU (GW1 and GW2) to 150 FTU (SW6) in rainy season and 0 FTU (GW1 and GW3) to 33 FTU (SW6) in dry season. The turbidity values for the groundwater for all the water samples except GW3 (at dry season) are within the recommended WHO limit of 5 FTU.

TDS values in the sampled water bodies range from $43 \mathrm{mg} / \mathrm{L}$ (SW5) to $560 \mathrm{mg} / \mathrm{L}$ (GW2) for rainy season samples while the values in the dry season, concentrations of TDS varied from $30 \mathrm{mg} / \mathrm{L}$ (SW5) to $270 \mathrm{mg} / \mathrm{L}$ (GW1). The TDS values recorded for ground and surface water samples in both seasons are within the WHO limit of $500 \mathrm{mg} / \mathrm{L}$ (WHO, 2004) with the exception of GW3 groundwater recording the value of $560 \mathrm{mg} / \mathrm{L} . \mathrm{Mg}^{2+}$ concentration varied from $5.1 \mathrm{mg} / \mathrm{L}$ (GW2) to $42.12 \mathrm{mg} / \mathrm{L}$ (GW1) during the rainy season and from $3.1 \mathrm{mg} / \mathrm{L} \mathrm{(GW2)} \mathrm{to} 38.21 \mathrm{mg} / \mathrm{L}$ (GW1) during the dry season exceeding the recommended limit of $0.2 \mathrm{mg} / \mathrm{L}$ set by the Nigerian Standard for Drinking Water Quality (SON, 2007). Phosphate concentrations in the water samples range from $0.09 \mathrm{mg} / \mathrm{L}$ in $\mathrm{SW} 3$ to $0.53 \mathrm{mg} / \mathrm{L}$ in SW2 (dry season) and $0.11 \mathrm{mg} / \mathrm{L}$ in GW1, GW2 and SW6 to $0.51 \mathrm{mg} / \mathrm{L}$ in SW2 (wet season). There is no WHO guideline value to compare the measured phosphate values.

The summary of both surface and ground water physico-chemical parameters during the wet and dry seasons are presented in Table 2(a and b). Most of the observed parameters have shown higher mean values at the wet season compared to dry season. The mean values of potassium have shown an exception, with higher values obtained in the dry season.

Table 1a. Physico-chemical parameter values in both surface and ground water samples during the rainy season in Igun-Ijesha, Osun state, Nigeria

\begin{tabular}{|c|c|c|c|c|c|c|c|c|c|c|c|c|c|}
\hline $\begin{array}{l}\text { Water } \\
\text { Samples }\end{array}$ & $\begin{array}{l}\text { Temp } \\
\left({ }^{\circ} \mathrm{C}\right)\end{array}$ & $\mathrm{pH}$ & $\begin{array}{l}\mathrm{EC} \\
(\mu \mathrm{S} / \mathrm{cm})\end{array}$ & $\begin{array}{l}\text { TDS } \\
(\mathrm{mg} / \mathrm{L})\end{array}$ & $\begin{array}{l}\text { Turb. } \\
\text { (FTU) }\end{array}$ & $\begin{array}{l}\mathrm{Cl}^{-} \\
(\mathrm{mg} / \mathrm{L})\end{array}$ & $\begin{array}{l}\mathrm{NO}_{3}^{-} \\
(\mathrm{mg} / \mathrm{L})\end{array}$ & $\begin{array}{l}\mathrm{PO}_{4}{ }^{3-} \\
(\mathrm{mg} / \mathrm{L})\end{array}$ & $\begin{array}{l}\mathrm{K}^{+} \\
(\mathrm{mg} / \mathrm{L})\end{array}$ & $\begin{array}{l}\mathrm{SO}_{4}{ }^{2-} \\
(\mathrm{mg} / \mathrm{L})\end{array}$ & $\begin{array}{l}\mathrm{Ca}^{2+} \\
(\mathrm{mg} / \mathrm{L})\end{array}$ & $\begin{array}{l}\mathrm{Mg}^{2+} \\
(\mathrm{mg} / \mathrm{L})\end{array}$ & $\begin{array}{l}\mathrm{Na}^{+} \\
(\mathrm{mg} / \mathrm{L})\end{array}$ \\
\hline SW1 & 26.1 & 8.14 & 100 & 100 & 9 & 8.71 & 0.04 & 0.21 & 4.12 & 13 & 16.19 & 10.14 & 11.02 \\
\hline SW2 & 26.3 & 8.05 & 110 & 100 & 18 & 6.16 & 0.03 & 0.51 & 3.08 & 22 & 16.32 & 12.25 & 11.41 \\
\hline SW3 & 26.1 & 8.06 & 100 & 98 & 21 & 5.23 & 0.04 & 0.20 & 3.10 & 13 & 15.51 & 12.24 & 10.52 \\
\hline SW4 & 26.2 & 7.90 & 110 & 91 & 22 & 6.38 & 0.03 & 0.12 & 2.98 & 15 & 20.06 & 13.10 & 10.15 \\
\hline SW5 & 26.3 & 8.53 & 160 & 43 & 29 & 6.23 & 0.02 & 0.24 & 4.78 & 4 & 9.30 & 6.72 & 7.24 \\
\hline SW6 & 26.7 & 7.71 & 90 & 86 & 150 & 6.43 & 0.02 & 0.11 & 3.11 & 4 & 10.41 & 9.61 & 10.01 \\
\hline GW1 & 25.7 & 8.53 & 620 & 68 & 5 & 71.02 & 0.02 & 0.11 & 150.70 & 80 & 65.05 & 42.12 & 24.62 \\
\hline GW2 & 25.6 & 7.50 & 80 & 390 & 5 & 6.23 & 0.02 & 0.11 & 3.15 & 4 & 25.16 & 5.10 & 6.05 \\
\hline GW3 & 25.2 & 8.55 & 270 & 560 & 9 & 30.40 & 0.04 & 0.13 & 57.63 & 53 & 39.60 & 15.89 & 15.35 \\
\hline WHO & & $6.5-8.5$ & 1000 & 500 & 5 & 250.00 & 50.00 & 3.00 & n.a & 100 & n.a & 0.2 .00 & 200.00 \\
\hline
\end{tabular}

Note: SW1: Oika River 1, SW2: Oika River 2, SW3: Oika River 3, SW4: Oika River 4, SW5: Eriper River, SW6: Justice Ibidapo River, GW1: Igunwell 1, GW2: Igun well 2, GW3: Ijana well, n.a: Not available, Temp-temperature, Turb-Turbidity 
Table 1b. Physico-chemical parameter values in both surface and ground water samples at dry season in Igun-Ijesha, Osun state, Nigeria

\begin{tabular}{|c|c|c|c|c|c|c|c|c|c|c|c|c|c|}
\hline $\begin{array}{l}\text { Water } \\
\text { Samples }\end{array}$ & $\begin{array}{l}\text { Temp } \\
\left({ }^{\circ} \mathrm{C}\right)\end{array}$ & $\mathrm{pH}$ & $\begin{array}{l}\mathrm{EC} \\
(\mu \mathrm{S} / \mathrm{cm})\end{array}$ & $\begin{array}{l}\text { TDS } \\
(\mathrm{mg} / \mathrm{L})\end{array}$ & $\begin{array}{l}\text { Turb. } \\
\text { (FTU) }\end{array}$ & $\begin{array}{l}\mathrm{Cl}^{-} \\
(\mathrm{mg} / \mathrm{L})\end{array}$ & $\begin{array}{l}\mathrm{NO}_{3}^{-} \\
(\mathrm{mg} / \mathrm{L})\end{array}$ & $\begin{array}{l}\mathrm{PO}_{4}^{3-} \\
(\mathrm{mg} / \mathrm{L})\end{array}$ & $\begin{array}{l}\mathrm{K}^{+} \\
(\mathrm{mg} / \mathrm{L})\end{array}$ & $\begin{array}{l}\mathrm{SO}_{4}{ }^{2-} \\
(\mathrm{mg} / \mathrm{L})\end{array}$ & $\begin{array}{l}\mathrm{Ca}^{2+} \\
(\mathrm{mg} / \mathrm{L})\end{array}$ & $\begin{array}{l}\mathrm{Mg}^{2+} \\
(\mathrm{mg} / \mathrm{L})\end{array}$ & $\begin{array}{l}\mathrm{Na}^{+} \\
(\mathrm{mg} / \mathrm{L})\end{array}$ \\
\hline SW1 & 27.1 & 6.54 & 218 & 40 & 6 & 4.81 & 0.05 & 0.21 & 4.29 & 11 & 15.19 & 9.27 & 10.97 \\
\hline SW2 & 28.2 & 6.22 & 218 & 50 & 14 & 5.57 & 0.03 & 0.53 & 4.05 & 21 & 15.48 & 10.19 & 11.14 \\
\hline SW3 & 28 & 6.5 & 210 & 40 & 21 & 4.60 & 0.05 & 0.09 & 3.23 & 13 & 14.51 & 10.13 & 10.28 \\
\hline SW4 & 27.9 & 6.37 & 205 & 50 & 14 & 4.38 & 0.03 & 0.1 & 3.23 & 11 & 19.07 & 11.13 & 10.25 \\
\hline SW5 & 27.3 & 6.62 & 103 & 30 & 19 & 4.17 & 0.01 & 0.24 & 4.88 & 2 & 8.95 & 5.59 & 6.72 \\
\hline SW6 & 26.7 & 6.04 & 183 & 40 & 33 & 4.43 & 0.01 & 0.1 & 3.28 & 2 & 9.73 & 8.36 & 9.99 \\
\hline GW1 & 26.1 & 6.64 & 138 & 270 & 0 & 65.59 & 0.01 & 0.12 & 158.66 & 65 & 63.02 & 38.21 & 24.18 \\
\hline GW2 & 26.4 & 6.18 & 818 & 40 & 1 & 4.25 & 0.01 & 0.12 & 4.81 & 2 & 21.08 & 3.10 & 6.55 \\
\hline GW3 & 26.3 & 5.95 & 1192 & 120 & 0 & 28.76 & 0.04 & 0.13 & 56.11 & 43 & 37.63 & 13.99 & 14.85 \\
\hline WHO & & $6.5-8.5$ & 1000 & 500 & 5 & 250.00 & 50.00 & 3.00 & n.a & 100 & n.a & 0.20 & 200.00 \\
\hline
\end{tabular}

STANDARD

Note: SW1: Oika River 1, SW2: Oika River 2, SW3: Oika River 3, SW4: Oika River 4, SW5: Eriper River, SW6: Justice Ibidapo River, GW1: Igunwell 1, GW2: Igun well 2, GW3: Ijana well, n.a: Not available, Temp-temperature, Turb-Turbidity

Note: Data in bold were higher than the WHO standard in drinking water

Table 2a. The summary of surface water parameters during the wet and dry seasons for Igun-Ijesha, Osun state, Nigeria $(\mathrm{n}=38)$

\begin{tabular}{|c|c|c|c|c|c|c|c|c|}
\hline \multirow[b]{2}{*}{ Variables } & \multicolumn{4}{|c|}{ Dry season } & \multicolumn{4}{|c|}{ Wet season } \\
\hline & Min. & Max. & Mean & Std Dev & Min. & Max. & Mean & Std Dev \\
\hline Temp $\left({ }^{\circ} \mathrm{C}\right)$ & 26.70 & 28.20 & 27.53 & 0.59 & 26.10 & 26.70 & 26.28 & 0.22 \\
\hline $\mathrm{pH}$ & 6.04 & 6.62 & 6.38 & 0.22 & 7.71 & 8.53 & 8.07 & 0.27 \\
\hline $\mathrm{EC}(\mu \mathrm{S} / \mathrm{cm})$ & 90.00 & 160.00 & 111.67 & 24.83 & 103.00 & 218.00 & 189.50 & 44.29 \\
\hline TDS (mg/L) & 30.00 & 50.00 & 41.67 & 7.53 & 43.00 & 100.00 & 86.33 & 21.95 \\
\hline Turbidity (mg/L) & 6.00 & 33.00 & 17.83 & 9.06 & 9.00 & 150.00 & 41.50 & 53.55 \\
\hline Chloride (mg/L) & 4.17 & 5.57 & 4.66 & 0.50 & 5.23 & 8.71 & 6.52 & 1.16 \\
\hline Nitrate $(\mathrm{mg} / \mathrm{L})$ & 0.01 & 0.05 & 0.03 & 0.02 & 0.02 & 0.04 & 0.03 & 0.01 \\
\hline Phosphate (mg/L) & 0.09 & 0.53 & 0.21 & 0.17 & 0.11 & 0.51 & 0.23 & 0.15 \\
\hline Potassium (mg/L) & 3.23 & 4.88 & 3.83 & 0.69 & 2.98 & 4.78 & 3.53 & 0.75 \\
\hline Sulphate (mg/L) & 2.00 & 21.00 & 10.00 & 7.21 & 4.00 & 22.00 & 11.83 & 6.91 \\
\hline Calcium (mg/L) & 8.95 & 19.07 & 13.82 & 3.82 & 9.30 & 20.06 & 14.63 & 4.04 \\
\hline Magnesium (mg/L) & 5.59 & 11.13 & 9.11 & 1.96 & 6.72 & 13.10 & 10.68 & 2.36 \\
\hline Sodium $(\mathrm{mg} / \mathrm{L})$ & 6.72 & 11.14 & 9.89 & 1.62 & 7.24 & 11.41 & 9.89 & 1.62 \\
\hline
\end{tabular}

Table 2b. The summary of ground water parameters during the wet and dry seasons for Igun-Ijesha, Osun state, Nigeria $(\mathrm{n}=38)$

\begin{tabular}{|c|c|c|c|c|c|c|c|c|}
\hline \multirow[b]{2}{*}{ Variables } & \multicolumn{4}{|c|}{ Dry season } & \multicolumn{4}{|c|}{ Wet season } \\
\hline & Min. & Max. & Mean & Std Dev & Mini. & Max. & Mean & Std Dev \\
\hline Temp $\left({ }^{\circ} \mathrm{C}\right)$ & 26.10 & 26.40 & 26.27 & 0.15 & 25.20 & 25.70 & 25.50 & 0.26 \\
\hline $\mathrm{pH}$ & 5.95 & 6.64 & 6.26 & 0.35 & 7.50 & 8.55 & 8.19 & 0.60 \\
\hline $\mathrm{EC}(\mu \mathrm{S} / \mathrm{cm})$ & 80.00 & 620.00 & 323.33 & 273.92 & 138.00 & 1192.00 & 716.00 & 534.35 \\
\hline TDS (mg/L) & 40.00 & 270.00 & 143.33 & 116.76 & 68.00 & 560.00 & 339.33 & 249.88 \\
\hline Turbidity (mg/L) & 0.00 & 1.00 & 0.33 & 0.58 & 5.00 & 9.00 & 6.33 & 2.31 \\
\hline Chloride (mg/L) & 4.25 & 65.59 & 32.87 & 30.88 & 6.23 & 71.02 & 35.88 & 32.74 \\
\hline Nitrate $(\mathrm{mg} / \mathrm{L})$ & 0.01 & 0.04 & 0.02 & 0.02 & 0.02 & 0.04 & 0.03 & 0.01 \\
\hline Phosphate (mg/L) & 0.12 & 0.13 & 0.12 & 0.01 & 0.11 & 0.13 & 0.12 & 0.01 \\
\hline Potassium (mg/L) & 4.81 & 158.66 & 73.19 & 78.33 & 3.15 & 150.70 & 70.49 & 74.61 \\
\hline Sulphate (mg/L) & 2.00 & 65.00 & 36.67 & 31.97 & 4.00 & 80.00 & 45.67 & 38.53 \\
\hline Calcium (mg/L) & 21.08 & 63.02 & 40.58 & 21.12 & 25.16 & 65.05 & 43.27 & 20.20 \\
\hline Magnesium (mg/L) & 3.10 & 38.21 & 18.43 & 17.97 & 5.10 & 42.12 & 21.04 & 19.04 \\
\hline Sodium $(\mathrm{mg} / \mathrm{L})$ & 6.55 & 24.18 & 15.19 & 8.82 & 6.05 & 24.62 & 15.19 & 8.82 \\
\hline
\end{tabular}


Ayantobo, O.O. et al. / American Journal of Environmental Sciences 10 (3): 289-300, 2014
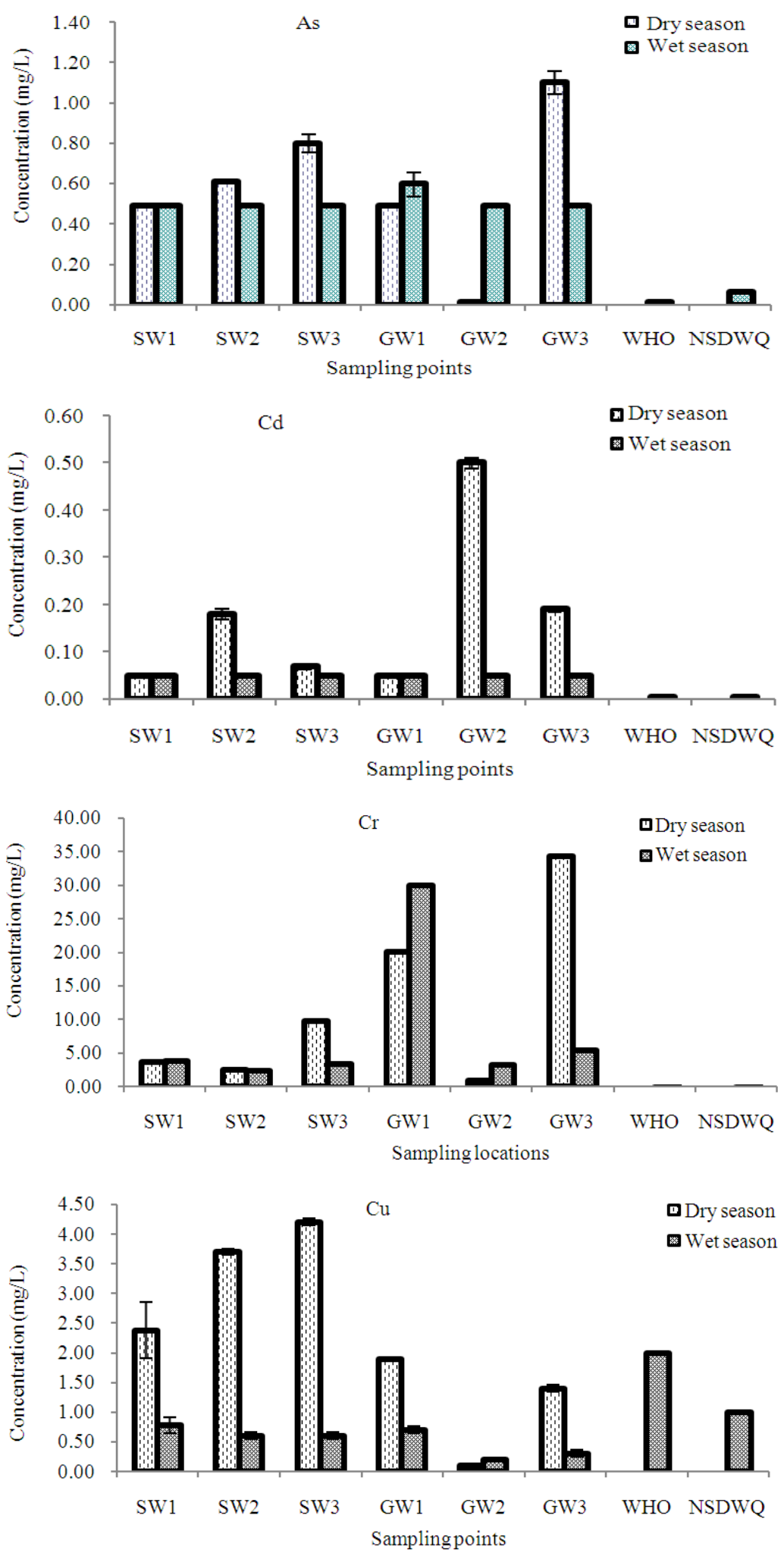

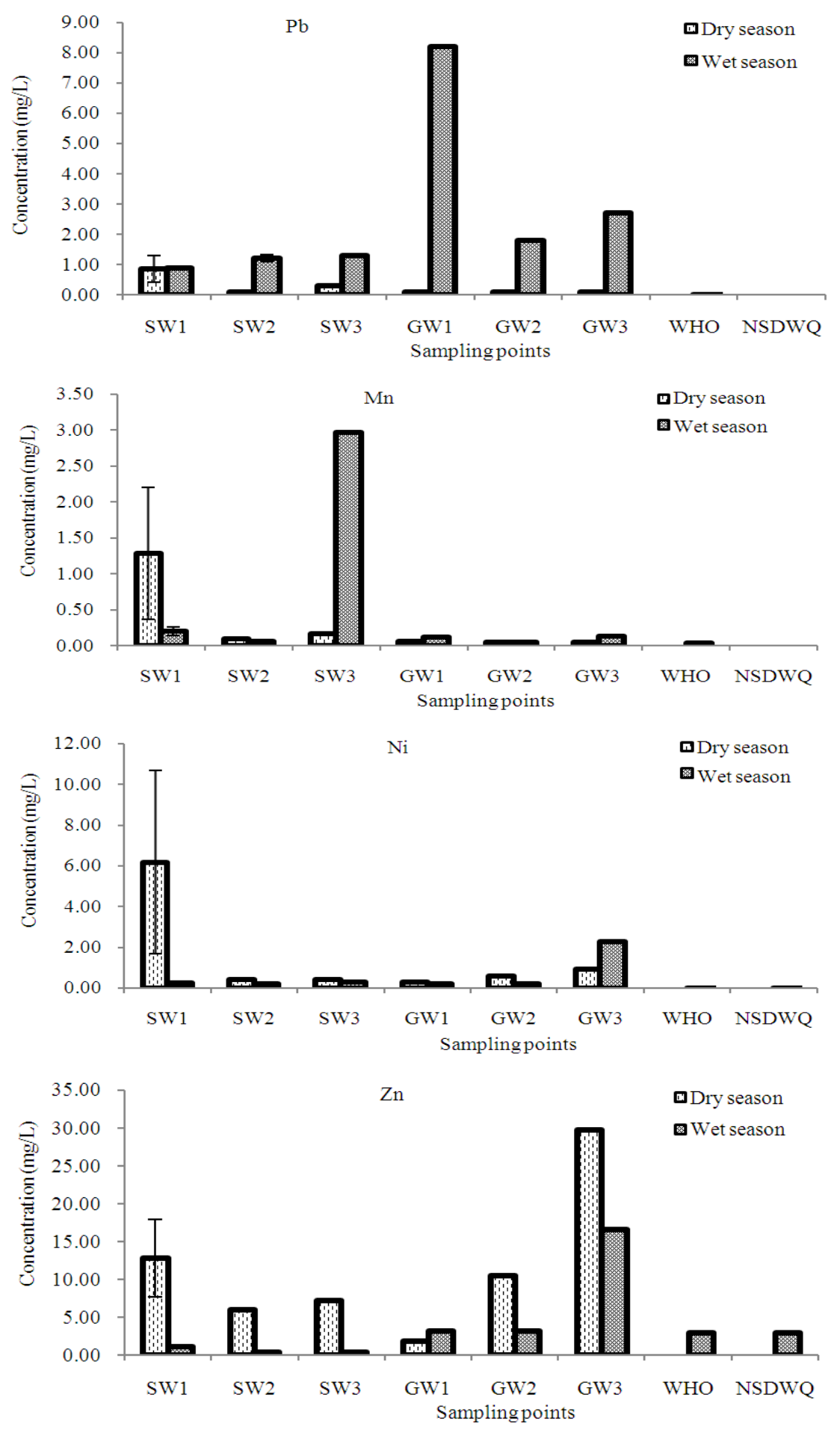

Fig. 2. Mean values of heavy metals in $(\mathrm{mg} / \mathrm{L})$ of both the surface and groundwater bodies in Igun-Ijesha, Osun state, Nigeria. The bars indicate the standard deviation. Note: SW1: Oika River, SW2: Eriperi River, SW3: Justice Ibidapo River, GW1: Igun well 1, GW2: Igun well 2, GW3: Ijana well 


\subsection{Heavy Metal Concentrations}

The mean values of heavy metals determined in the water samples at both seasons are shown in Fig. 2. The concentration of arsenic ranges $0.49-0.70 \mathrm{mg} / \mathrm{L}$ during the rainy season to $0.01-1.20 \mathrm{mg} / \mathrm{L}$ in dry season samples; cadmium concentration is between 0.05 and $0.50 \mu \mathrm{g} / \mathrm{L}$, with the highest value observed in GW2 sample during the dry season and the lowest concentration in SW1 during the wet season. The concentrations of $\mathrm{Cr}$ range from $2.30-30.50 \mathrm{mg} / \mathrm{L}$ during the rainy season and $0.80-34.80 \mathrm{mg} / \mathrm{L}$ during the dry season, which exceeded the recommended limit set by the WHO and NSDWQ. The values of $\mathrm{Cu}$ range from $0.18-1.10 \mathrm{mg} / \mathrm{L}$ (rainy season) to $0.09-4.30 \mathrm{mg} / \mathrm{L}$ (dry season); nickel values are $0.10-2.40 \mathrm{mg} / \mathrm{L}$ (rainy season) and $0.05-9.60 \mathrm{mg} / \mathrm{L}$ (dry season); while zinc range 0.49 $16.70 \mathrm{mg} / \mathrm{L}$ (rainy season) to $1.8-29.90 \mathrm{mg} / \mathrm{L}$ (dry season). The concentration of $\mathrm{Pb}$ ranged from $0.80-8.30$ $\mathrm{mg} / \mathrm{L}$ (rainy season) to $0.09-0.31 \mathrm{mg} / \mathrm{L}$ (dry season).

\section{DISCUSSION}

Based on the guidelines, the $\mathrm{pH}$ of water sources from the study area may not adversely affect its suitability for drinking and domestic purposes, as well as aquatic ecosystem. On the contrary, groundwater $\mathrm{pH}$ at location GW3 during the dry season is below the WHO limit suggesting possible acidity. Schafer et al. (2009) and Ayantobo et al. (2013) in previous studies reported that low $\mathrm{pH}$ in groundwater may be due to natural geochemical and biochemical processes within the aquifers. The GW3 sampling point is within the mining and processing facilities, it is thus possible that seepage of effluent discharges, as well as surface and agricultural run-off may contribute to the increased concentration of ions. The elevated EC content may also be due to the weathering of sulphide-bearing rocks, which is facilitated by the on-going mining activities (Marcovecchio et al., 2007; Ayantobo et al., 2013). Turbidity is a major concern for surface water in particular during the rainy seasons (Schafer et al., 2009). Elevated turbidity values are expected during the wet season due to erosion of organic materials and solids into the water bodies (http://water.epa.gov/scitech/wastetech/guide/stormwater /upload/2006_10_31_guide_stormwater_usw_b.pdf).

Water turbidity can also be attributed to the presence of clays in surface water. Pathogens and bacteria can be measured in turbidity (Schafer et al., 2009).

According to Karikari and Ansa-Asare (2006), the palatability of water with TDS level less than $600 \mathrm{mg} / \mathrm{L}$ is generally considered to be good whereas water with TDS above $1,200 \mathrm{mg} / \mathrm{L}$ becomes increasingly unpalatable. The highest TDS concentration recorded at GW3 may be due to seepage of effluent discharges, as well as agriculture and domestic waste substances (Ayantobo et al., 2013).

This study has found higher concentration of $\mathrm{Mg}^{2+}$ than that reported by Muhammad et al. (2011) for drinking water in the Kohistan region, Northern Pakistan. $\mathrm{Mg}^{2+}$ occurs naturally in water after passage through mineral deposits and rock strata and suggests that $\mathrm{Mg}^{2+}$ contributes to total hardness of water in the study area.

Comparing the values of phosphate concentration obtained in this study with that of natural water (usually between 0.005 and $0.02 \mathrm{mg} / \mathrm{L}$ (Taiwo et al., 2010; DebRoy et al., 2012); it can be concluded that, this study has recorded elevated phosphate values in groundwater samples. High concentrations of phosphate could indicate the presence of pollution and are largely responsible for eutrophication conditions in water bodies (Taiwo et al., 2012). The high phosphate loads recorded at the sampling points may be attributed to inflows from eroded materials carried from waste rock dumpsite (Taiwo et al., 2010; DebRoy et al., 2012). Elevated Phosphate level could also be related to the weathering of calcium-bearing minerals largely facilitated by mining activities in the area (Singh et al., 2008).

Calcium and potassium are not a health concern and are not regulated (Schafer et al., 2009). Although, the reported values may not implicate the public health, however, the presence of multivalent cations such as $\mathrm{Ca}$ may pose negative treatment's implications for certain processes (Schafer et al., 2009).

Arsenic concentrations are well above the recommended WHO limit of $0.01 \mathrm{mg} / \mathrm{L}$ (except GW2 sample). The Arsenic concentration could be due to mineral dissolutions such as pyrite oxidation. Previous study of Kortatsi (2004) has reported Arsenic concentrations of 0.05 and $0.14 \mathrm{mg} / \mathrm{L}$ in ground and surface water. Elevated amount of Arsenic observed in this can be damaging to public health on persistent exposures through consumption. Arsenic is a known carcinogen (Roy and Saha, 2002). Skin cancer has been associated with long-term exposure to arsenic through drinking water (Kortatsi, 2007). Early clinical symptoms of acute intoxication of Arsenic include abdominal pain, vomiting, diarrhoea, muscular pain and body weakness (Tchounwou et al., 2003). Cadmium occurs naturally with zinc and lead in sulphide ores. Cd concentrations in unpolluted natural waters are usually below $1.0 \mu \mathrm{g} / \mathrm{L}$. In this study, Cd concentrations in surface and groundwater at both seasons are higher than the permissible limit. The guideline value for cadmium is given as $0.003 \mathrm{mg} / \mathrm{L}$ in 
drinking water by both the World Health Organization (WHO, 2004) and the Nigerian standard for drinking water quality (SON, 2007). Previous studies show maximum levels in groundwater to be $0.003 \mathrm{mg} / \mathrm{L}$ (Kortatsi, 2004; Armah et al., 2010) and $0.06 \mathrm{mg} / \mathrm{L}$ (Oluwasanya and Martins, 2006). Maximum levels in surface water were less than $0.05 \mathrm{mg} / \mathrm{L}$ (Kuma and Younger, 2004; Yem et al., 2013). The observed cadmium values show that water quality in the study area is questionable and unfit for human consumption. As a practical measure, the guideline is set as $0.05 \mathrm{mg} / \mathrm{L}$, which is considered to be unlikely to give rise to significant risks to health (WHO, 2004). Maximum levels in groundwater has been shown to be $0.07 \mathrm{mg} / \mathrm{L}$ (Kortatsi, 2004; Marcovecchio et al., 2007) and 0.06 $\mathrm{mg} / \mathrm{L}$ (Oluwasanya and Martins, 2006) and in surface water to be $0.49 \mathrm{mg} / \mathrm{L}$ (Kuma and Younger, 2004, Marcovecchio et al., 2007). The observed elevated chromium concentrations represent an identified hazard, which calls for necessary control measures to mitigate consequent health impacts.

Copper is both an essential nutrient and a drinkingwater contaminant. During the rainy season, copper concentration in the surface and groundwater sampled are within the acceptable limits of 2.0 and $1.0 \mathrm{mg} / \mathrm{L}$ set by WHO and NSDWQ, respectively. Exceptions are Justice Ibidapo River (SW3), Eriperi River (SW2) and Oika River (SW1); the observed values are below the permissible level. The present findings show much lower values than the concentrations of copper in the Indus River, Pakistan (5.0 mg/L) and Mississippi, USA (River $(4.0 \mathrm{mg} / \mathrm{L})$. Lead is a possible human carcinogen and it is also a cumulative poison so that any increase in the lead burden should be avoided. The $\mathrm{Pb}$ values in this study revealed clear excedeencies relative to the permissible limit of $0.001 \mathrm{mg} / \mathrm{L}$ set by the WHO. Previous studies also show maximum levels in groundwater to be $0.03 \mathrm{mg} / \mathrm{L}$ (Kortatsi, 2004, Armah et al., 2010) and in surface water to be $<0.05 \mathrm{mg} / \mathrm{L}$ (Kuma and Younger, 2004; Yem et al., 2013). A provisional tolerable daily intake is set as $3.5 \mu \mathrm{g}$ of lead per $\mathrm{kg}$ of body weight for infants. Human health concerns associated with lead intoxication in children include brain damage, behavioral problems, anaemia, liver and kidney damage and hearing loss (Gohar and Mohammadi, 2010; Rajaganapathy et al., 2011) whereas in adults poor muscle coordination, nerve damage to the sense organs, increased blood pressure, hearing and vision impairment, reproductive problems and retarded fetal development (Surendran and El-Fawal, 2008). In this respect, the lead content in the surface and groundwater within the mine area are dangerous for human health and aquatic life.
Manganese concentrations above $0.1 \mathrm{mg} / \mathrm{L}$ can impact an undesirable taste to drinking water. Effects from manganese are primarily to the central nervous system (Wasserman et al., 2006; Bhattacharya et al., 2008; Bada et al., 2012). Surface water bodies investigated in this study had Mn concentrations (0.06-2.97 mg/L) above the WHO guideline value of $0.04 \mathrm{mg} / \mathrm{L}$ (WHO, 2004). Ground water sources sampled in the study area also recorded $\mathrm{Mn}$ concentrations (0.05-0.13 $\mathrm{mg} / \mathrm{L})$ above WHO guideline. The high Mn concentration level (2.97 $\mathrm{mg} / \mathrm{L}$ ) detected in Ibidapo River, which is within vicinity of the mines can be attributed to anthropogenic sources such as effluent discharges and acid-mine drainage from mining activities. It can also be linked to natural geochemical and biochemical processes such as weathering of manganese bearing minerals and rocks within the aquifers (Singh et al., 2008). Nickel concentrations in drinking water are normally below 20 $\mu \mathrm{g} / \mathrm{L}$, although levels up to several hundred micrograms per litre in groundwater and drinking water have been reported (Obiri et al., 2010). The concentrations of nickel observed in the present study are above the permissible limit of $0.07 \mathrm{mg} / \mathrm{L}$ for WHO standard and $0.02 \mathrm{mg} / \mathrm{L}$ of NSDWQ for domestic water (SON, 2007). The observed nickel values also exceed the findings of Kortatsi (2004), Oluwasanya and Martins (2006) who found maximum levels in groundwater to be $0.08 \mathrm{mg} / \mathrm{L}$ and $0.34 \mathrm{mg} / \mathrm{L}$ respectively. The presence of nickel in the study area is a chemical hazard to both aquatic biota of the river as well as for human consumption. Zn concentration of the surface water sampled during the rainy season are within the recommended limits of 3 $\mathrm{mg} / \mathrm{L}$ set by the WHO and NSDWQ while value from sampling point GW1 during the dry season also are within the limit. Zinc is an essential trace element found in virtually all food and potable water in the form of salts or organic complexes (Edema et al., 2001; WHO, 2003).

\section{IMPLICATIONS FOR MINING MANAGEMENT POLICES}

The findings of this study hold several implications for water quality management and policy. Previously, most mining communities depended on surface water as drinking water source. However, contamination of surface water particularly via mining activities made it imperative for government and other non-state stakeholders to resort to groundwater (Armah et al., 2010). Results from this study and other studies (Obiri et al., 2010) have shown that the quality of groundwater is similarily, questionable. The results identifying many water 
quality hazards also revealed that the surface and groundwater extracted from the vicinity of the mine cannot be considered safe for particularly drinking and other domestic purposes. Policy makers need to be aware for appropriate regulations that would make it mandatory to analyze drinking water for physical and chemical parameters in mining communities on a regular basis. Where water sources have been tested, communities should be notified of contaminant levels so as to inform apt household or communal treatment solutions and daily decision-making regarding access to safe drinking water.

\section{CONCLUSION}

The main goal of this study was to assess the effect of mining activities on water quality sampled at Igun Ijesha gold mine district. The results from this study showed that water resources (surface and ground water) within the vicinity of the study area are contaminated. The hydrochemistry of both surface and groundwater show seasonal variation probably due to natural variations in geology and the mining activities. The results also indicated that the values of most of the observed physicochemical parameters of water samples are found within the standards set by the WHO. Elevated values are observed for most parameters in the wet season while $\mathrm{K}^{+}$revealed higher concentrations in the dry season. The heavy metal concentrations are generally higher than the WHO recommended limit indicating threats to public health.

This study, therefore, recommends that activities of miners should be monitored to ensure that gold extraction and other mining activities do not occur close to drinking water sources. The miners and the entire community should be educated on the health risk associated with human exposure to trace metals to prevent pollution of water bodies. The recommended immediate control measures to the identified water supply and quality problem in the study area is provision of alternative water supply and treatment of metal contaminated water, in the short and medium term to protect health and well being of the rural people living in the vicinity of the mine. IgunIjesha is located within the humid tropics with 7-8 months of adequate rainfall. Rainwater harvesting for drinking purposes has been generally reported as a common practice (Oluwasanya, 2006). Rainwater harvesting may thus be considered as an alternative option for water supply in Igun-Ijesha. Piped water supply may be considered as the ultimate goal for safe water provision in the study area such that safe water can be delivered in close proximity of the consumers. Apart from hand-dug wells and boreholes, other water supply options for the household level includes solar distillation, solar disinfection, sand house hold filters and engaging the services of water vendors. Overall, the results presented in this study indicate the critical need for a clearly laid out water safety planning to mitigate public health risk in the study area.

\section{ACKNOWLEDGMENT}

The researchers acknowledged the Federal University of Agriculture, Abeokuta for the support given to Olusola Ayantobo for his Masters of Science programme.

\section{REFERENCES}

Ademeso, O.A., J.A Adekoya and A Adetunji, 2013. Further evidences of cataclasis in the Ife-Ilesa schist belt, Southwestern Nigeria. J. Natural Sci. Res., 11: 50-59.

Armah, F.A., S. Obiri, D.O. Yawson, E.E. Onumah and G.T. Yengoh et al., 2010. Anthropogenic sources and environmentally relevant concentrations of heavy metals in surface water of a mining district in Ghana: A multivariate statistical approach. J. Environ. Sci. Health Tox. Hazard. Subst. Environ. Eng., 45: 1804-1813. DOI: 10.1080/10934529.2010.513296

Aslibekian, O. and R. Moles, 2003. Environmental risk assessment of metals contaminated soils at silver mines abandoned mine site, co tipperary, Ireland. Environ. Geochem. Health, 25: 247-266. DOI: 10.1023/A:1023251102402

Awomeso, J.A., A.M. Taiwo, A.M. Gbadebo and A.O. Arimoro, 2010. Waste disposal and pollution management in urban areas: A workable remedy for the environment in developing countries. Am. J. Environ. Sci., 6: 260-32. DOI: 10.3844/ajessp.2010.26.32

Ayantobo, O.O, G.O. Oluwasanya, O.A. Idowu and O.A. Eruola, 2013. Water quality evaluation of hand-dug wells in ibadan, oyo state, Nigeria. Global Journals Inc.

Bada, B.S. and T.A. Olarinre, 2012. Characteristics of soils and heavy metal content of vegetation in oil spill impacted land in Nigeria. Proceedings of the Annual International Conference on Soils, Sediments, Water and Energy, (SWE’ 12). 
Bhattacharya, A.K., S.N. Mandal and S.K. Das, 2008. Heavy metals accumulation in water, sediment and tissues of different edible fishes in upper stretch of Gangetic West Bengal. Trends Applied Sci. Res., 3: 61-68. DOI: 10.3923/tasr.2008.61.68

Chung, J.H., P.S. Kang, C.Y. Kim, K.S. Lee and G.T. Kim et al., 2005. Blood $\mathrm{Pb}$, urine $\mathrm{Cd}$ and health assessment of residents in the vicinity of abandoned mines in Gyeongsangbuk-do. Korean J. Occup. Environ. Med., 17: 225-237.

DebRoy, S., S. Das, S. Ghosh, S. Banerjee and D. Chatterjee et al., 2012. Isolation of nitrate and phosphate removing bacteria from various environmental sites. OnLine J. Biol. Sci., 12: 62-71. DOI: $10.3844 /$ ojbsci.2012.62.71

Edema, M.O., A.M. Omemu and O.M. Fapetu, 2001. Microbiology and physicochemical analysis of different sources of drinking water in Abeokuta, Nigeria. J. Microbiol., 15: 57-61.

Ettler, V., B. Kř́́bek, V. Majer, I. Knésl and M. Mihaljevič, 2011. Differences in the bioaccessibility of metals/metalloids in soils from mining and smelting areas (Copperbelt, Zambia). J. Geochem. Explorat., 113: 68-75. DOI: 10.1016/j.gexplo.2011.08.001

García-Lorenzo, M.L., C. Pérez-Sirvent, M.J. MartínezSánchez and J. Molina-Ruiz, 2011. Trace elements contamination in an abandoned mining site in a semiarid zone. J. Geochem. Explorat., 113: 23-35 DOI: 10.1016/j.gexplo.2011.07.001

Gashi, F., N. Troni, F. Faiku, F. Laha and A. Haziri et al., 2013. Chemical and statistical analyses of elements in river water of morava e binces. Am. J. Environ. Sci., 9: 142-155. DOI: 10.3844/ajessp.2013.142.155

Gohar, A.V. and A. Mohammadi, 2010. Epigenetic effects of carcinogens. J. Biol. Sci., 10: 200-208. DOI: $10.3923 /$ jbs.2010.200.208

Karikari, A.Y. and O.D. Ansa-Asare, 2006. Physicochemical and microbial water quality assessment of Densu river of Ghana. West Africa J. Applic. Ecol., 12: 87-100. DOI: 10.4314/wajae.v10i1.45701

Kortatsi, B.K., 2004. Hydrochemistry of groundwater in the mining area of Tarwa-Prestea, Ghana. Ph.D. Thesis, University of Ghana, Legon-Accra, Ghana.

Kortatsi, B.K., 2007. Groundwater quality in the wassa west district of the western region of Ghana. West African J. Applied Ecol., 11: 31-31. DOI: 10.4314/wajae.v11i1.45729
Krishna, A.K., M. Satyanarayanan and P.K. Govil, 2009. Assessment of heavy metal pollution in water using multivariate statistical analysis in an industrial area: A case study from Patancheru, Medak District andhra Pradesh India. J. Hazardous Materials, 167: 366-373. DOI: 10.1016/j.jhazmat.2008.12.131

Kuma, J.S. and P.L. Younger, 2004. Water quality trends in the Tarkwa gold-mining district, Ghana. Bull. Eng. Geol. Environ., 63: 119-132. DOI: 10.1007/s10064-004-0227-8

Lone, M.I., Z. HE, P.J. Stoffella and X. Yang, 2008. Phytoremediation of heavy metals polluted soils and water: Progress and perspectives. J. Zhej. Univ. Sci., 9: 210-220. DOI: 10.1631/jzus.B0710633

Marcovecchio, J.E., S.E. Botte and R.H. Freije, 2007. Heavy Metals, Major Metals, Trace Elements. In: Handbook of Water Analysis, L.M. Nollet (Ed.), CRC Press, London, ISBN-10: 1420006312, pp: 275-311.

Muhammad, S., M.T. Shah and S. Khan, 2011. Health risk assessment of heavy metals and their source apportionment in drinking water of Kohistan region, northern Pakistan. Microchemical J., 98: 334-343. DOI: 10.1016/j.microc.2011.03.003

NMC, 1987. Nigerian Mining Corporation. Mining industry of Nigeria retrieved from.

Nomanbhay, S.M. and K. Palanisamy, 2005. Removal of heavy metal from industrial wastewater using chitosan coated oil palm shell charcoal. Elec. J. Biotechnol.

Obiri, S., D.K. Dodoo, D.K. Essumang and F.A. Armah, 2010. Cancer and non-cancer risk assessment from exposure to arsenic, cadmium and copper by resident adults and children in the Obuasi Municipality, Ghana. Int. J. Human Ecol. Risk Assess., 16: 651665. DOI: 10.1080/10807031003788907

Oluwasanya, G.O., 2006. Assessment of rainwater harvesting in rural household water supply-a case of Otofure village, Erua/Ishan region, Edo State, Nigeria. J. Nigerian Meteorol. Soc., 6: 70-81.

Oluwasanya, G.O. and O. Martins, 2006. Assessment of heavy metals in groundwater case study of Ogun State-Southern Nigeria. Asset Series A, 6: 309-321.

Rajaganapathy, V., F. Xavier, D. Sreekumar and P.K. Mandal, 2011. Heavy metal contamination in soil, water and fodder and their presence in livestock and products: A review. J. Environ. Sci. Technol., 4: 234-249. DOI: 10.3923/jest.2011.234.249 
Roy, P. and A. Saha, 2002. Metabolism and toxicity of arsenic: A human carcinogen. Current Sci., 82: $38-45$.

Schafer, A.I., H.M.A. Rossiter, P.A. Owusu, B.S. Richards and E. Awuah, 2009 Physico-chemical water quality in Ghana: Prospects for water supply technology implementation. Desalination, 248: 193-203. DOI: 10.1016/j.desal.2008.05.055

Singh, A.K., G.C. Mondal, S. Kumar, T.B. Singh and B.K. Tewary et al., 2008. Major ion chemistry, weathering processes and water quality assesment in upper catchment of Damodar River basin, Ind. Environ. Geol., 54: 745-758. DOI: 10.107/s00254-007-0860-1

SON, 2007. Nigerian standard for drinking water quality. Plot 1689 lome street, Wuse Zone 7, Abuja, Nigeria.

Sracek, O., B. Kř́íbek, M. Mihaljevič, V. Majer and F. Veselovský et al., 2011. Mining-related contamination of surface water and sediments of the Kafue River drainage system in the Copperbelt district, Zambia: An example of a high neutralization capacity system. J. Geochemical. Explorat., 112: 174-188. DOI: 10.1016/j.gexplo.2011.08.007

Surendran, G. and H.A.N. El-Fawal, 2008. Neuroimmune responses to toxic agents: Comparison of organometal electrophiles using detection of antibodies to neural cytoskeleton and myelin as biomarkers. J. Pharmacol. Toxicol., 3: 173-189. DOI: 10.3923/jpt.2008.173.189

Taiwo, A.M., 2013. Receptor modeling of industrial air pollutants. Ph.D. Thesis, University of Birmingham, UK.

Taiwo, A.M., A.O. Adeogun, K.A. Olatunde and K.I. Adegbite, 2010. Analysis of groundwater quality of hand-dug wells in peri-urban area of Obantoko, Abeokuta, Nigeria for selected physico-chemical parameters. Pacific J. Sci. Technol., 12: 527-535.
Taiwo, A.M., O.O. Olujimi, O. Bamgbose and T.A. Arowolo, 2012. Surface Water Quality Monitoring. In: Nigeria: Situational Analysis and Future Management Strategy, Water Quality Monitoring and Assessment, Voudouris (Ed.), ISBN: 978-95351-0486-5

Tchounwou, P.B., A.K. Patlollab and J.A. Centeno, 2003. Invited reviews: Carcinogenic and systemic health effects associated with arsenic exposure-a critical review. Toxicol. Pathol., 31: 575-588. DOI: 10.1080/01926230390242007

Thermo Fischer Scientific Inc, 2012. Dionex ICS-2100 Ion Chromatography System Operator's Manual. Document No. 065291.

TML, 1996. Tropical Mines Limited. A Pre-Investment Study of the Primary Goldmine-Odo Ijesa (primary) Gold Deposit Report, 2: 1-12.

USEPA, 1989. Risk assessment guidance for superfund, volume $\mathrm{i}$, human health evaluation manual. EPA/54 0/1-89/002, Office of Emergency and Remedial Response, Washington, DC.

Wasserman, G.A., X.H. Liu, F. Parvez, H. Ahsan, D. Levy and P. Factor-Litvak et al., 2006. Water manganese exposure and children's intellectual function in araihazar, Bangladesh. Environ. Health Perspect., 114: 124-129. PMID: 16393669

WHO, 2003. Total dissolved solids in drinking: Background document for the development of WHO guidelines for drinking-water quality. Geneva.

WHO, 2004. WHO Guidelines for Drinking Water Quality. 3rd Edn., World Health OrganisationGeneva.

Yem, T., N.X. Hai, N.M. Khai and N.X. Huan, 2013. Study for improving an Duong Lake water quality for chi Lang Nam stork island conservation and ecotourism development. Am. J. Environ. Sci., 9: 218-225. DOI: 10.3844/ajessp.2013.218.225 